\title{
Homogenous Bone Grafts as an Alternative in Oral Rehabilitation Treatments with Dental Implants
}

\author{
Los Injertos Óseos Homogéneos como una Alternativa en los \\ Tratamientos de Rehabilitación Oral con Implantes Dentales
}

\begin{abstract}
Jefferson David Melo de Matos'; Leonardo Jiro Nomura Nakano'; Severino Alexandre Babosa da Silva²; Jaqueline Alves do Nascimento²; Geórgia Maria Granja Aureliano2; Valdir Cabral Andrade3; Marco Antonio Bottino4; John Eversong Lucena de Vasconcelos ${ }^{5}$; Guilherme da Rocha Scalzer Lopes ${ }^{1}$
\end{abstract}

\begin{abstract}
MATOS, J. D. M.; NAKANO, L. J. N.; SILVA, S. A. B.; NASCIMENTO, J. A.; AURELIANO, G. M. G.; ANDRADE, V. C.; BOTTINO, M. A.; VASCONCELOS, J. E. L.; LOPES, G. R. S. Homogenous bone grafts as an alternative in oral rehabilitation treatments with dental implants. Int. J. Odontostomat., 14(4):678-684, 2020.
\end{abstract}

ABSTRACT: The present study aims to describe, through a case report, the functioning of bone grafts, where they are obtained including bone banks and the different dental areas in which it is used. A 50-year.old female patient HMR, sought the postgraduate college of dentistry CECAPE for oral rehabilitation. The initial clinical examination revealed the absence of several dental elements in both the maxilla and mandible, bone resorption in the entire maxillary extension where there was an absence of elements in the anterior region and the presence of a torus in the palatal region. Initial tomographic examinations of the maxilla and mandible were performed, looking for the best conduct regarding the diagnosis and planning of the case. After the clinical and radiographic examinations was performed, and the diagnosis was reached, it was determined as a treatment for oral rehabilitation of the maxilla, bone grafting and an Implant-supported Removable Partial Prosthesis and for the mandible a Dento-muco-supported Removable Partial Prosthesis. Dental treatments and oral rehabilitation from the use of bone tissues and bone grafting have become commonly used. Procedures that would normally lead to failure started to increase the percentage of successes due to the use of these biomaterials. The use of bone grafts in dentistry has been shown to be a very effective and useful resource, considering its great applicability in bone reconstructions in different areas of dentistry. interface.

KEY WORDS: bone transplantation, dental implants, bone and bones, alveolar bone grafting, bone-implant

\section{INTRODUCTION}

Bone is a specialized, vascularized and dynamic connective tissue that has undergone numerous changes over the years (Matos et al., 2019). In this context, it presents itself as a plastic structure formed by crystals of calcium phosphate in the form of hydroxyapatite arranged on a collagen matrix (Lima et al., 2017; Matos et al., 2017, 2019). In order to maintain the normal conditions of the individual, a constant remodeling occurs in the bone structure, whether in relation to mechanical or metabolic properties (Matos et al., 2019; Moussa \& Dym, 2020).
Formed by cells, bone also assumes the role of tissue, these cells being responsible for the remodeling and repair of this structure forming a new bone or fibrous tissue (Begam et al., 2017). It is worth mentioning that, when injured, has a unique capacity for regeneration and repair without the presence of scars, but in some situations due to the size of the defect, the bone tissue cannot completely regenerate. In these special cases, it is necessary to perform bone grafting procedures (Begam et al.; Lima et al., 2017; Matos et al.; Moussa \& Dym).

\footnotetext{
${ }^{1}$ Department of Dental Materials and Prosthodontics, São Paulo State University (Unesp), Institute of Science and Technology, São José dos Campos - SP, Brazil.

${ }^{2}$ Centro Universitário Leão Sampaio UNILEAO, Juazeiro do Norte - CE, Brazil.

${ }^{3}$ Department of Dentistry, Universidade Federal de Juiz de Fora UFJF, Governador Valadares - MG, Brazil.

${ }^{4}$ Program in Restorative Dentistry, Department of Dental Materials and Prosthodontics, São Paulo State University (Unesp), Institute of Science and Technology, São José dos Campos - SP, Brazil.

${ }^{5}$ Department of Implantology, College of Dentistry CECAPE, Juazeiro do Norte - CE, Brazil.
} 
MATOS, J. D. M.; NAKANO, L. J. N.; SILVA, S. A. B.; NASCIMENTO, J. A.; AURELIANO, G. M. G.; ANDRADE, V. C.; BOTTINO, M. A.; VASCONCELOS, J. E. L.; LOPES, G. R. S. Homogenous bone grafts as an alternative in oral rehabilitation treatments with dental implants. Int. J. Odontostomat., 14(4):678-684, 2020.

Due to its high regenerative capacity, this tissue in turn gains notoriety in this way, being used in transplants and grafts in the most diverse areas; standing out in Dentistry allowing functional and aesthetic oral rehabilitation (Logeart-Avramoglou et al., 2005). Many dental specialties such as Periodontics, maxillofacial surgery and traumatology, implantology and orthodontics make use of this resource to treat regions with impaired bone condition (Pinto et al., 2007; Matos et al., 2019).

Bone grafts are biomaterials and can originate from several sources; there are currently a large number of biomaterials available for these treatments, classified as: Autograft: when it comes from the individual; Allograft: when obtained from another individual of the same species; Isogenic: from different individuals, but of the same species and genetically identical to the individual receiving the graft (identical twins or therapeutic cloning); Alloplast: can be of metallic, ceramic or polymeric nature; Xenograft: obtained from individuals of different species of the recipient (for example, bovine) (Begam et al.; Lima et al., 2017, 2018a; Matos et al., 2019).

With regard to bone behavior, the bone proceeds in several ways, which are Osteogenic: it refers to the biomaterial's capacity to take viable bone cells to the recipient bed; Osteoinductive: refers to the biomaterial's ability to induce undifferentiated mesenchymal cells in the recipient bed to differentiate into osteoblasts; Osteoconductive: refers to the biomaterial's capacity to act as a framework for bone neoformation in the recipient bed, allowing cell migration and blood vessel proliferation into the biomaterial (Pinto et al., 2007; Egusa et al., 2012; Lima et al., 2018b; Matos et al., 2019).

Currently, when bone replacement is needed, different options can be used by the dental surgeon (Jesus-Garcia \& Feofiloff, 1996). However, the first choice for grafting is autogenous bone, as it is the gold standard and has a high capacity to produce bone, easy bone remodeling, maintenance of immature bone over time, stabilization of implants, has low antigenicity, minimal risk of infection and easy availability (Pinto et al., 2007; Lima et al., 2018a). These, in turn, can be obtained from different regions of the body, the crest of the iliac bone (spongy bone marrow grafts), the skullcap, tibia, ribs and mandible (especially for smaller grafts) the areas election donors; obtaining autografts is sometimes coated with some morbidity (Jesus-Garcia \& Feofiloff). On the other hand, in children, the amount of graft is often insufficient; the lack of an adequate amount of bones to fill large defects has been increasing the use of fresh and frozen homografts, for which there is still no satisfactory synthetic substitute and in sufficient numbers (Abramowicz et al., 2012).

The bones used as a graft in the jaw regions are in most cases, obtained from the individual himself, removed from the anterior part of the mandible where there are no noble structures to be damaged by the process of obtaining the graft (Roos et al., 2000; Pinto et al., 2007; Lima et al., 2017; Matos et al.; Lima et al., $2018 b)$. When the amount of this biomaterial is not sufficient to cover the entire area to be grafted, it is necessary to obtain material previously stored in suitable places called bone bank (Tomford et al., 1983; Stefani et al., 1989; Roos et al.).

In Brazil, transplants began in 1964, where the first organ to be transplanted was a kidney in 1968; followed by heart, liver, intestine and pancreas (Piovesan \& Nahas, 2018; Matos et al., 2019). With the evolution of technological medicine, the bone graft started to be used mainly in orthopedic procedures, as well as in small oral rehabilitation (Tomford et al.; Piovesan \& Nahas). However, due to the growing need to use these grafts, bone banks were created to store and supply bone when requested, although there are rules and criteria to regulate the donation of this type of tissue (Tomford et al.; Bettin et al., 1994; Hardin, 1994; Piovesan \& Nahas; Pego-Fernandes \& Garcia, 2010; Souza et al., 2010; Matos et al., 2019).

The first bone bank created in Brazil was in Passo Fundo (RS) in 1982, but around the world these establishments already existed: Holland in 1953 and Russia in the 60s; these storage locations use freezers at temperatures of $-70^{\circ} \mathrm{C}$ which are safe in the bone bank room (Piovesan \& Nahas; Pego-Fernandes \& Garcia; Souza et al.). One of the most well-known bone banks in Brazil is that of Hospital São Paulo in the Surgical Center, where in this area it has its own generators, avoiding power outages for a prolonged time (Piovesan \& Nahas). Refrigerators are equipped with tachographs that record temperatures on paper charts and these bones are stored for at least 180 days so that cases in which these same bone tissues are grafted are studied and confirmed that no pathology from that tissue has developed in the receivers for the same period. If any pathology is confirmed, it is then discarded; otherwise this tissue can be stored for up to five years (Bettin et al.; Hardin; Piovesan \& Nahas; Pego-Fernandes \& Garcia; Souza et al.). 
MATOS, J. D. M.; NAKANO, L. J. N.; SILVA, S. A. B.; NASCIMENTO, J. A.; AURELIANO, G. M. G.; ANDRADE, V. C.; BOTTINO, M. A.; VASCONCELOS, J. E. L.; LOPES, G. R. S. Homogenous bone grafts as an alternative in oral rehabilitation treatments with dental implants. Int. J. Odontostomat., 14(4):678-684, 2020.

Today in dentistry, bone grafts are used in aesthetic-functional recovery in patients who have suffered dentoalveolar trauma, traumatic dental extractions, pathologies involving the maxilla and mandible, among others, with bone loss derived from periodontal diseases, traumatic surgery or even from physiological form due to lack of occlusion and masticatory forces (Bettin et al.; Hardin; Pinto et al., 2007; Matos et al., 2019).

In this context, the present study aims to describe through a case report, the functioning of bone grafts, where they are obtained including bone banks and the different dental areas in which it is employed.

\section{CASE REPORT}

A 50-year-old female patient HMR, sought the postgraduate college of dentistry CECAPE for oral rehabilitation. The initial clinical examination in the upper arch revealed the absence of elements 15 to 22 and 24 to 26 , bone resorption in the entire maxillary extension in the anterior region and the presence of a torus in the palatal region (Figs. 1A, B). In the lower arch (mandible), there was an absence of elements $37,36,46,47$ and 48 and bone resorption in the edentulous area.

Initial tomographic examinations of the maxilla and mandibles were performed, looking for the best conduct regarding the diagnosis and planning of the case. Computed tomography of the right side in axial, panoramic and parasagital sections of the maxilla revealed great bone resorption and the presence of a palatine torus leading to the closure of the atrophic maxilla diagnosis (Figs. 2A-D).

The mandibular tomographic report indicated the absence of elements $37,36,46,47$ and 48 , moderate atrophy of the alveolar ridge in the edentulous region (Figs. 3A, B), a hyperdense area with a characteristic of sclerosing osteitis in the apical region of teeth 32 to 35 (Fig. 3C, D). These clinical findings were validated because a reconstruction of the 3D slices with $1 \mathrm{~mm}$ thickness and $1 \mathrm{~mm}$ spacing was performed, either through a panoramic, axial, transversal or oblique view.
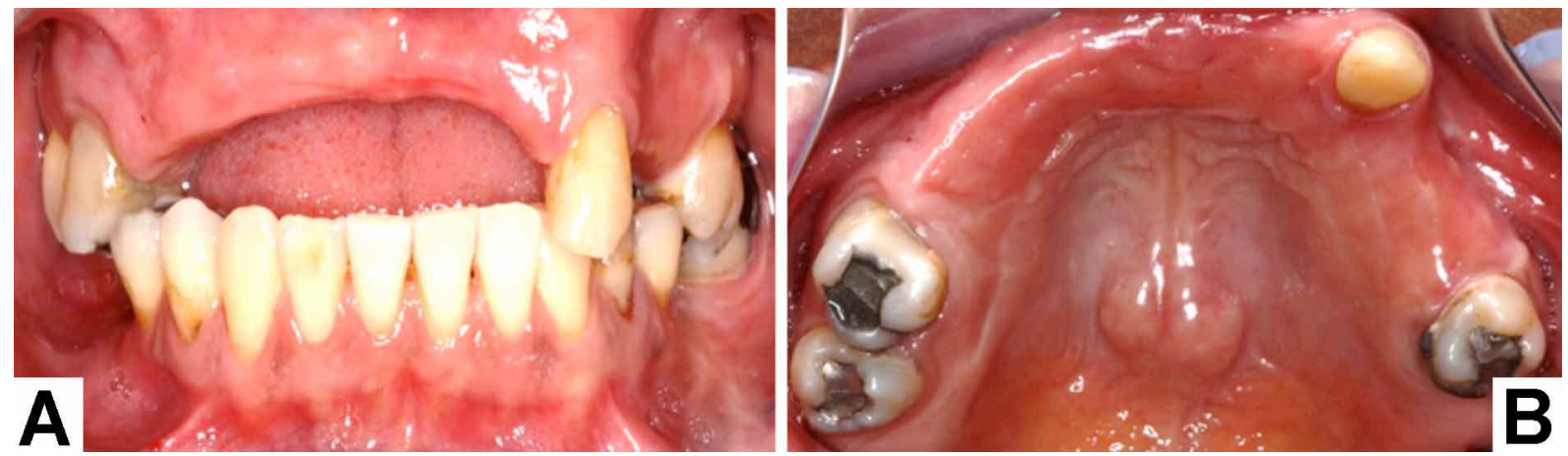

Fig. 1. A, B. Initial clinical examination showing the edentulous area and the palatine torus. Imaging tests were requested to determine the extent of bone loss in the jaws.
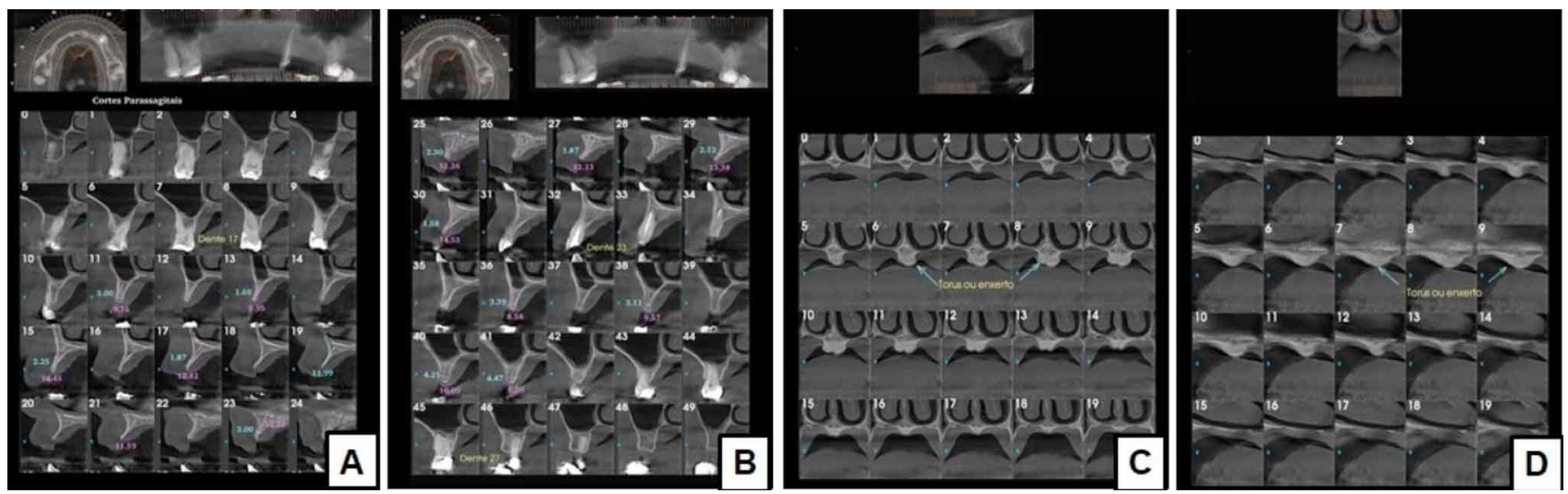

Fig. 2. A, B. Computed tomography of the right and left sides in axial, parasagital and panoramic sections showing maxillary atrophy of the right side. C, D. Computed tomography of the maxilla in parasagital sections showing palatine torus. 

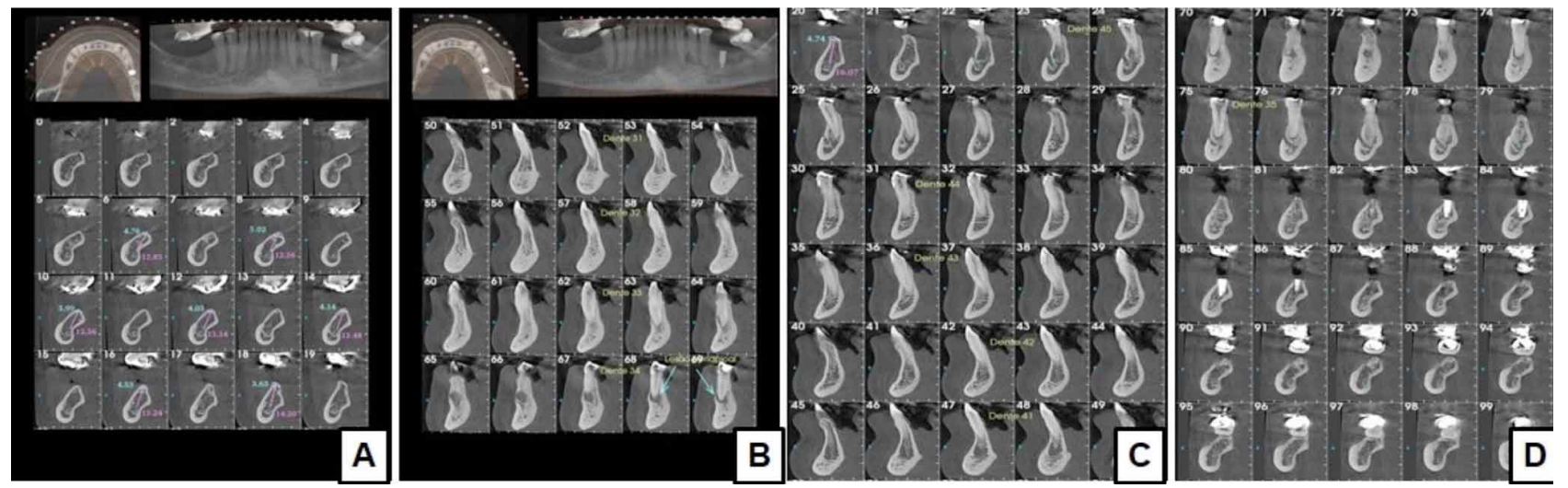

Fig. 3. A, B. Computed tomography of the mandible in axial, transversal and panoramic sections. Absence of elements 37,36 , 46,47 and 48 , moderate atrophy of the alveolar ridge in the edentulous region. C, D. Computed tomography of the mandible in oblique views of a hyperdense area with a characteristic of sclerosing osteitis in the apical region of the teeth 32 to 35 .

After clinical and radiographic examinations and diagnosis, treatment for oral rehabilitation of the maxilla was determined. This consisted of bone grafting and an implant-supported removable partial prosthesis, and for the mandible a Dento-muco-supported removable partial prosthesis. To perform oral maxillary rehabilitation, a bone graft was needed in the anterior region of the maxilla. A bone tissue request form containing the registration data and authorization, completed and signed by the patient receiving the tissue, where she presented herself authorizing the graft in view of the success or failure of the procedure at the [Skeletal Muscle Tissue Bank of the University of Marília - SP (Banco de Tecidos Músculo
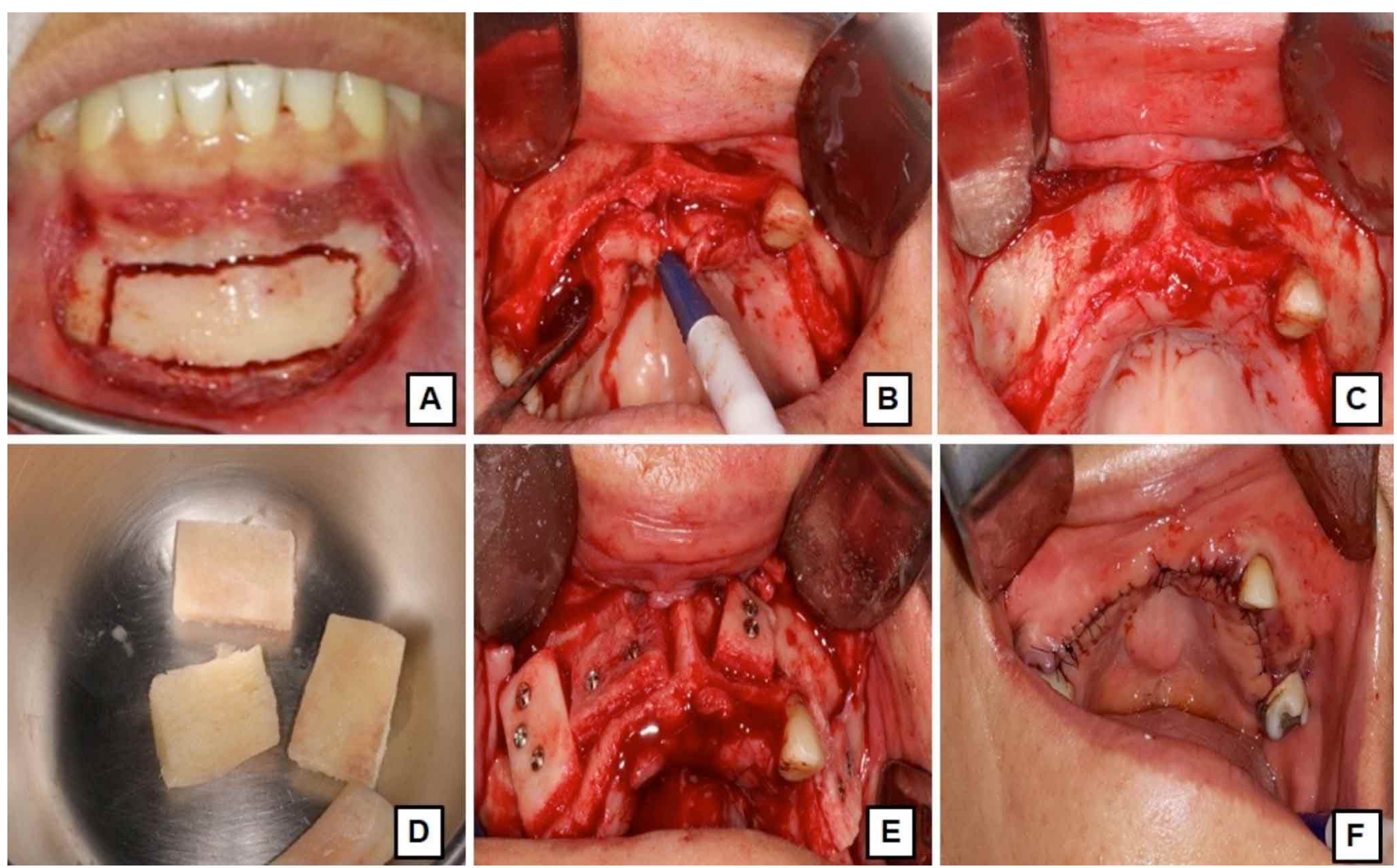

Fig. 4. A. Spongy cortical block measuring $15 \times 10 \times 06 \mathrm{~cm}$ characterized by a homograft obtained from the anterior mandible region. $\mathrm{B}, \mathrm{C}$. Incision in the edentulous maxillary ridge and detachment until full access to the maxillary bone. D. Bone tissue divided into four blocks. E. The tissue to be grafted was fixed to the maxillary buccal bone with screws. F. Repositioned and sutured tissue. 
MATOS, J. D. M.; NAKANO, L. J. N.; SILVA, S. A. B.; NASCIMENTO, J. A.; AURELIANO, G. M. G.; ANDRADE, V. C.; BOTTINO, M. A.; VASCONCELOS, J. E. L.; LOPES, G. R. S. Homogenous bone grafts as an alternative in oral rehabilitation treatments with dental implants. Int. J. Odontostomat., 14(4):678-684, 2020.

Esqueléticos da Universidade de Marília - SP UNIOSS)]. The tissue used in the procedure was a spongy cortical block measuring $15 \times 10 \times 06 \mathrm{~cm}$ characterized by a homograft obtained from the anterior region of the mandible and stored at $-80^{\circ} \mathrm{C}$ Skeletal Muscle Tissue Bank of the University of Marília (Fig. 4A). The surgical procedure started with an incision in the edentulous and detached maxillary ridge, until total access to the maxillary bone (Figs. 4B, C). The tissue to be grafted was divided into four smaller blocks and fixed to the maxillary buccal bone with screws, and then the incised and detached tissue was initially repositioned and sutured (Figs. 4D, E, F). Thus, 176 days after bone grafting surgery, a new tomographic exam was performed, showing that there was no
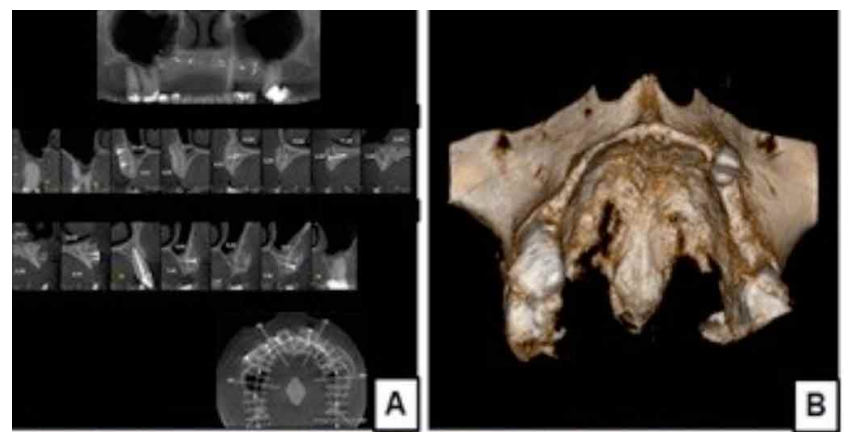

resorption of the grafted tissue, but bone neoformation enabling implants to be performed (Fig. 5A).

To plan the performance of the implants, computer program ImplantViewer 3.201 was used, which is a surgical planning software that allows virtual simulations of treatment plans that increase the safety of the surgery and allow the predictability of the ideal implants to be used, allowing the orientation of surgical guides from the planning made in the software (Figs. 5B, C, D). Then, another surgical procedure was performed, with eight implants distributed, planned and a Removable Partial Prosthesis was made and installed, thus rehabilitating the patient (Figs. 5E, F, G).
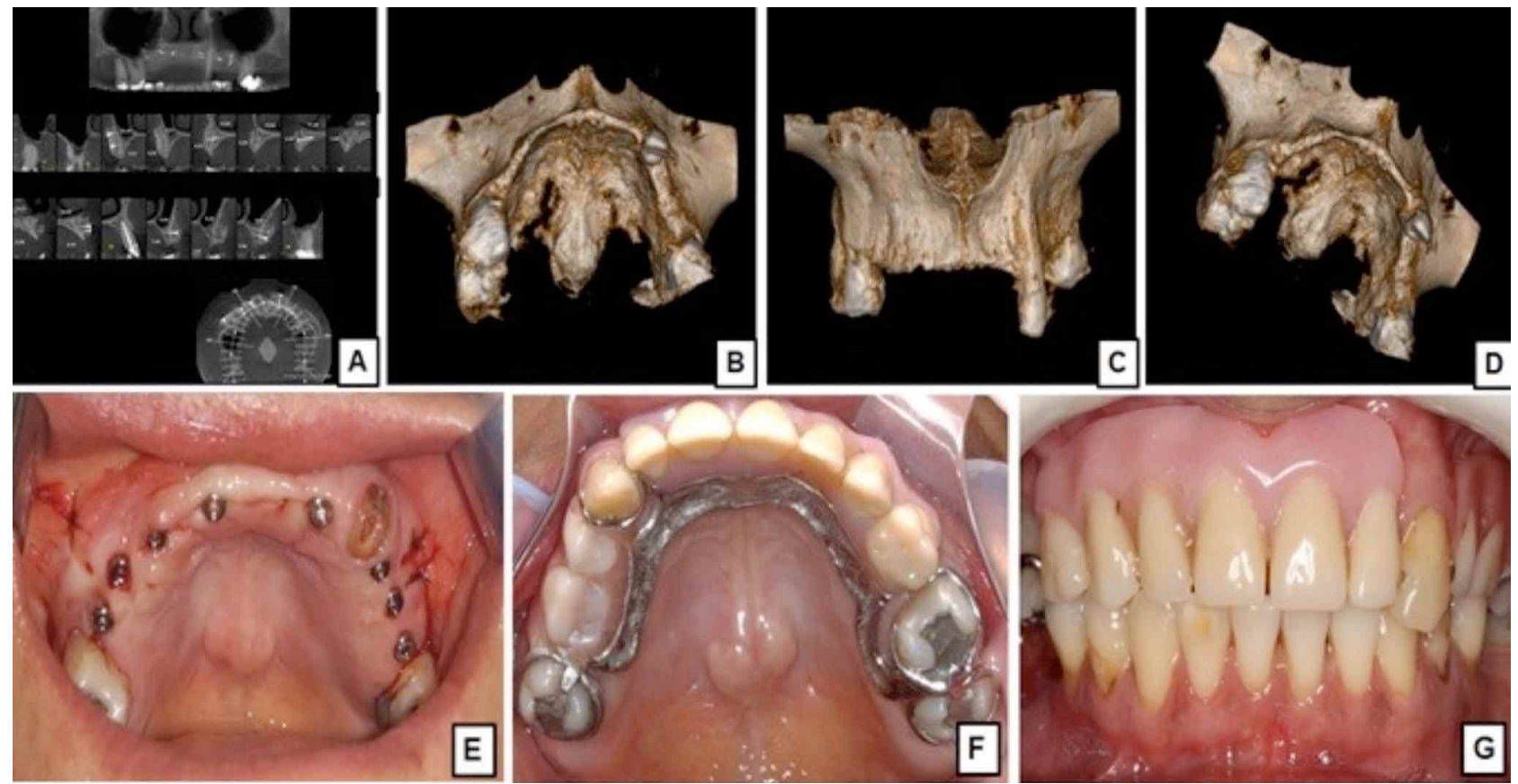

Fig. 5. A. Computed tomography showing that there was no resorption of the grafted tissue, but a new bone formation. B, C, D. Implantviewer Program 3.201. E. Bone tissue divided into four blocks. F, G. Oral rehabilitation with Implant-supported Removable Partial Prosthesis.

\section{DISCUSSION}

Dental treatments and oral rehabilitation with the use of bone tissues and bone grafting have become common (Bettin et al.; Hardin; Aljohani et al., 2018). Procedures that would normally lead to failure started to increase the percentage of successes due to the use of these biomaterials (Aljohani et al.).

Allograft bone tissues like the one used in the case described are quite effective because they come from individuals of the same species, and may be osteogenic, osteoinductive and osteoconductive (Kim et al., 2017; Matos et al., 2019).

During the course of the treatment, it was observed that computed tomography scans of approximately six months after the graft showed relevant characteristics, such as a marked neoformation with control of bone tissue behavior. Added to this, is not only the migration of viable bone 
MATOS, J. D. M.; NAKANO, L. J. N.; SILVA, S. A. B.; NASCIMENTO, J. A.; AURELIANO, G. M. G.; ANDRADE, V. C.; BOTTINO, M. A.; VASCONCELOS, J. E. L.; LOPES, G. R. S. Homogenous bone grafts as an alternative in oral rehabilitation treatments with dental implants. Int. J. Odontostomat., 14(4):678-684, 2020.

cells to the recipient bed, but also the ability to act as a framework for neoformation in the grafted surgical bed (Bettin et al.; Hardin; Logeart-Avramoglou et al.; Kim et al.; Lima et al., 2017; Aljohani et al.; Lima et al., 2018a). Therefore, there was a cell migration with proliferation of blood vessels into the biomaterial (Logeart-Avramoglou et al.; Begam et al.; Lima et al., 2017; Matos et al.; Moussa \& Dym; Matos et al., 2019).

It is worth mentioning that the graft of this biomaterial also supplies mechanical support, as the patient's oral rehabilitation provided the installation of implants for posterior adaptation of a prosthesis (Bettin et al.; Hardin; Logeart-Avramoglou et al; Begam et al.; Kim et al.; Lima et al., 2017; Matos et al.; Santos et al., 2017; Windhager et al., 2017; Aljohani et al.; Proêza et al., 2018; Moussa \& Dym). The clinical success of this type of procedure depends on knowledge of the biological principles of bone repair, in addition to the surgical technique and proper graft manipulation (Kim et al.; Pereira et al., 2017; Santos et al.; Windhager et al.; Proêza et al.).

Numerous researches are carried out in order to affirm which the ideal implant material would be, to replace the autogenous graft (Bettin et al.; Hardin; Logeart-Avramoglou et al.; Begam et al.; Kim et al.; Lima et al., 2017; Matos et al.; Santos et al.; Windhager et al.; Aljohani et al.; Lima et al., 2018b; Proêza et al.; Moussa \& Dym). However, this is still one of the greatest challenges of implantology, due to the lack of an ideal graft material; for that, this type of material must follow seven principles: 1) unlimited supply without compromising the donor area; 2) promote osteogenesis; 3 ) not showing an immune response from the host; 4) revascularize quickly; 5) stimulate osteoinduction; 6) promote osteoconduction; 7) be completely replaced by bone in quantity and quality similar to that of the host (Bettin et al.; Hardin; Logeart-Avramoglou et al.; Pinto et al.; Tolstunov, 2009; Kim et al.; Lima et al., 2017; Matos et al.; Windhager et al.; Aljohani et al.; Jo et al., 2018; Lima et al., 2018a; Lopes \& Matos, 2018; Prando et al., 2018; Albanese et al., 2019; Moussa \& Dym; Matos et al., 2019).

Despite being a challenge, autogenous grafts are elected as the first choice, either for their efficiency, biosafety or ease of obtaining them. Thus, the use of bone grafts represents a viable alternative in the attempt to regenerate lost bone tissue (Tolstunov; Jo et al.; Lima et al., 2018b; Lopes \& Matos; Prando et al.; Albanese et al.).

\section{CONCLUSION}

It can be concluded from this study that:The use of bone grafts in dentistry has been shown to be a very effective and useful resource, considering its great applicability in bone reconstructions in different areas of dentistry. Associated or not with autogenous grafts in the repair of bone tissue and regardless of the guarantee of success in procedures that use this resource, it is important that studies continue to be done on this subject so that a synthetic material is able to dispense with the need to obtain it through extra-oral surgeries that may cause greater morbidity for the patient.

MATOS, J. D. M.; NAKANO, L. J. N.; SILVA, S. A. B.; NASCIMENTO, J. A.; AURELIANO, G. M. G.; ANDRADE, V. C.; BOTTINO, M. A.; VASCONCELOS, J. E. L.; LOPES, G. R. S. Los injertos óseos homogéneos como una alternativa en los tratamientos de rehabilitación oral con implantes dentales. Int. J. Odontostomat., 14(4):678-684, 2020.

RESUMEN: El presente estudio tiene como objetivo describir a través de un informe de caso, el funcionamiento de los injertos óseos, donde se obtienen, incluidos los bancos de huesos y las diferentes áreas dentales en las que se emplea. Una paciente HMR, de 50 años de edad, asistió el centro universitario de posgrado CECAPE para rehabilitación oral. El examen clínico inicial reveló la ausencia de varios dientes tanto en el maxilar como en la mandíbula, la resorción ósea en toda la extensión maxilar donde había ausencia de dientes en la región anterior y la presencia de un torus en la región palatina. Se realizaron exámenes tomográficos iniciales del maxilar y mandíbula, buscando la mejor conducta con respecto al diagnóstico y la planificación del caso. Después de los exámenes clínicos y radiográficos realizados y el diagnóstico listo, se determinó como un tratamiento para la rehabilitación oral del maxilar, el injerto óseo y una prótesis removible implantosoportada y para la mandíbula una prótesis parcial removible dento-mucosoportada. Los tratamientos dentales y la rehabilitación oral a partir del uso de tejidos óseos y el injerto óseo se han utilizado comúnmente. Los procedimientos que normalmente conducirían al fracaso comenzaron a aumentar el porcentaje de éxitos debido al uso de estos biomateriales. Se ha demostrado que el uso de injertos óseos en odontología es un recurso muy eficaz y útil, considerando su gran aplicabilidad en las reconstrucciones óseas en diferentes áreas de la odontología.

PALABRAS CLAVE: trasplante óseo, implantes dentales, huesos, injerto de hueso alveolar interfase hueso-implante. 
MATOS, J. D. M.; NAKANO, L. J. N.; SILVA, S. A. B.; NASCIMENTO, J. A.; AURELIANO, G. M. G.; ANDRADE, V. C.; BOTTINO, M. A.; VASCONCELOS, J. E. L.; LOPES, G. R. S. Homogenous bone grafts as an alternative in oral rehabilitation treatments with dental implants. Int. J. Odontostomat., 14(4):678-684, 2020.

\section{REFERENCES}

Abramowicz, S.; Katsnelson, A.; Forbes, P. W. \& Padwa, B. L. Anterior versus posterior approach to iliac crest for alveolar cleft bone grafting. J. Oral Maxillofac. Surg., 70(1):211-5, 2012.

Albanese, M.; Ricciardi, G.; Luciano, U.; Donadello, D.; Lucchese, A.; Gelpi, F.; Zangani, A.; De Santis, D.; Rizzini, A.; Rossetto, A.; et al. Alveolar splitting with Piezosurgery ${ }^{\circledR}$, bone bank grafts and NobelActive implants as an alternative to major bone grafting for maxillary reconstruction. Minerva Stomatol., 68(1):3-10, 2019.

Aljohani, W.; Ullah, M. W.; Zhang, X. \& Yang, G. Bioprinting and its applications in tissue engineering and regenerative medicine. Int. J. Biol. Macromol., 107(Pt. A):261-75, 2018

Begam, H.; Nandi, S. K.; Kundu, B. \& Chanda, A. Strategies for delivering bone morphogenetic protein for bone healing. Mat. Sci. Eng. C Mat. Biol. Appl., 70(Pt. 1):856-69, 2017.

Bettin, D., Dethloff, M., Steinbeck, J., \& Polster, J. Organization of a bone and tissue bank. Z. Orthop. Ihre. Grenzgeb., 132(6):453-8, 1994.

Egusa, H.; Sonoyama, W.; Nishimura, M.; Atsuta, I. \& Akiyama, K. Stem cells in dentistry--Part II: Clinical applications. J. Prosthodont. Res., 56(4):229-48, 2012.

Hardin, C. K. Banked bone. Otolaryngol. Clin. North Am., 27(5):91125, 1994.

Jesus-Garcia, R. \& Feofiloff, E. T. Técnicas de obtenção, processamento, armazenamento e utilização de homoenxertos ósseos. Rev. Bras. Ortop., 31(11):895-903, 1996.

Jo, S. H.; Kim, Y. K. \& Choi, Y. H. Histological evaluation of the healing process of various bone graft materials after engraftment into the human body. Materials (Basel), 11(5):714, 2018.

Kim, Y. K.; Pang, K. M.; Yun, P. Y.; Leem, D. H. \& Um, I. W. Longterm follow-up of autogenous tooth bone graft blocks with dental implants. Clin. Case Rep., 5(2):108-18, 2017.

Lima, J. F. M.; Matos, J. D. M.; Santos, J. P. S.; Oliveira, A. J. A. G.; Vasconcelos, J. E. L.; Zogheib, L. V. \& Castro, D. S. Maxillary sinus lift surgery techniques: A literature review. Int. J. Adv. Res., 5(8):832-44, 2017.

Lima, J. L. O.; Sendyk, D. I.; Sendyk, W. R.; Polo, C. I.; Correa, L.m\& Deboni, M. C. Z. Growth dynamic of allogeneic and autogenous bone grafts in a vertical model. Braz. Dent. J., 29(4):325-34, 2018a

Lima, L. G.; Pereira, A. L. C.; Matos, J. D. M.; Lopes, G. R. S.; Vasconcelos, J. E. L. \& Pita-Neto, I. C. Treatment techniques for oroantral communications and fistulas. Int. J. Adv. Rese., 6(7):634-48, 2018b.

Logeart-Avramoglou, D.; Anagnostou, F.; Bizios, R. \& Petite, H. Engineering bone: challenges and obstacles. J. Cel. Mol. Med., 9(1):72-84, 2005

Lopes, G. R. S. \& Matos, J. D. M. Principais fatores de risco nas falhas precoces e tardias em implantes dentários: uma revisão de literatura. J. Public Health Dent., 9(2):1-10, 2018.

Matos, J. D. M.; Santos, I. K. S.; Perreira, A. L. C.; Oliveira, A. J. A. G.; Vasconcelos, B. C. G.; Pita Neto, I. C. \& Vasconcelos, J. E. $\mathrm{L}$. The use of the rich fibrin in platelets and leukocytes as alternative treatment for lifting the maxillary sinus - A literature review. Int. J. Dev. Res., 7(6):13436-441, 2017.

Matos, J. D. M.; Diamantino, P. J. S.; Nishioka, R. S.; Bottino, M. A.; Lopes, G. R. S. \& Andrade, V. C. El uso de injertos óseos en la práctica dental. Rev. Nacion. Odont., 15(29):1-11, 2019.

Moussa, N. T. \& Dym, H. Maxillofacial Bone Grafting Materials. Dent. Clin. North Am., 64(2):473-90, 2020.

Pego-Fernandes, P. M. \& Garcia, V. D. Estado atual do transplante no Brasil. Rev. Diagn. Trat., 15(2):51-2, 2010.

Pereira, A. L. C.; Matos, J. D. M.; Cavalcante-Pereira, N.; Franco, J. M. P. L.; Vasconcelos, B. C. G.; Vardiero, V. A.; Gomes, T. N. \&
Vasconcelos, J. E. L. Maxillary Sinus lift and use of L-PRF with a delayed installation of implants-Case report. Int. J. Dev. Res., 7(6):13174-7, 2017

Pinto, J. G. S.; Ciprandi, M. T. O.; Aguiar, R. C.; Lima, P. V. P.; Hernandez, P. A. G. \& Junior, A. N. S. Enxerto autógeno $x$ biomateriais no tratamento de fraturas e deformidades faciais Uma revisão de conceitos atuais. Rev. Fac. Odontol., 12(3):7984, 2007

Piovesan, A. \& Nahas, W. C. Estado atual do transplante renal no Brasil e sua inserção no contexto mundial. Rev. Med., 97(3):3349, 2018.

Prando, R. H. N.; Balestrassi, R. B.; Andrade, P. K.; Matos, J. D. M.; Diamantino, P. J. S.; Vasconcelos, J. E. L.; Lopes, G. R. S.; Dias, E. C. L. C. M. \& Chiarelli, F. M. Use of mucoderm ${ }^{\circledR}$ collagen matrix in peri-implant aesthetic defect correction. Int. J. Dev. Res., 6(8):336-44, 2018.

Proêza, A. P.; Corteletti, M. M.; Balbino, H. C. G.; Chiarelli, F. M.; Matos, J. D. M. \& Lopes, G. R. S. Guided bone regeneration with biomaterial use and reaboresorvable membrane: A case report. Int. J. Dev. Res., 6(5):884-90, 2018.

Roos, M. V.; Junior, A. C. \& Michelin, A. F. Procedimentos de um banco de ossos e a aplicabilidade dos enxertos por ele proporcionados. Acta Ortop. Bras., 8(3):122-7, 2000.

Santos, I. K. S.; Matos, J. D. M.; Júnior, C. U. F. S.; Oliveira, A. J. A. G.; Franco, J. M. P. L.; Vasconcelos, B. C. G.; Vasconcelos, E. M. G. M.; Gomes, T. N.; Vardiero, V. A. \& Vasconcelos, J. E. L. Surgery of the maxillary sinus with piezocirurgic system use: Case report. Int. J. Inf. Res. Rev., 4(6): 4258-4260, 2017.

Souza, D. O.; Junior, E. A.; Barreto, I. C.; Oliveira, T. F. L. \& Araujo, R. P. C. Aplicações de enxertos de bancos de ossos em Odontologia. Rev. Cienc. Med. Biol., 9(1):45-8, 2010.

Stefani, A. E.; Oliveira, L. F. M. D. \& Fernandez, P. Banco de osso: um método simplificado. Rev. Bras. Ortop., 24(3):66-72, 1989.

Tolstunov, L. Maxillary tuberosity block bone graft: innovative technique and case report. J. Oral Maxillofac. Surg., 67(8):17239, 2009.

Tomford, W. W.; Doppelt, S. H.; Mankin, H. J. \& Friedlaender, G. E. 1983 bone bank procedures. Clin. Orthop. Rel. Res., (174):1521, 1983

Windhager, R.; Hobusch, G. M. \& Matzner, M. Allogeneic transplants for biological reconstruction of bone defects. Orthopade, 46(8):656-64, 2017

Corresponding author:

Jefferson David Melo de Matos

D.D.S.; M.D.; Ph.D. Student

Post Graduate Student - Ph.D Program

Department of Dental Materials and Prosthodontics

São Paulo State University (Unesp)

Institute of Science and Technology

Avenue Engenheiro Francisco José Longo - 777/778

Jardim São Dimas

São José dos Campos, SP

CEP: 12245000

BRAZIL

Email: matosjefferson19@gmail.com

Received: 01-05-2020

Accepted: 04-07-2020 